\title{
ETHNOBOTANICAL STUDY OF MEDICINAL PLANTS USED BY THARU COMMUNITY OF PARROHA VDC, RUPANDEHI DISTRICT, NEPAL
}

\author{
Rajendra Acharya* and Kamal Prasad Acharya** \\ *Arunodaya Higher Secondary School, Satikhel, Kathmandu, Nepal. \\ **P.O. Box 15142 KPC 676, Kathmandu, Nepal.
}

\begin{abstract}
The indigenous knowledge on medicinal plants is gaining recognition worldwide because of its support in discovery of new medicines and its importance for proper conservation of biodiversity. Present study aims to explore the ethnobotanical information on medicinal plants used by Tharu community of Pahhoha VDC of Rupandehi district. The study was conducted during different periods of the year 2007. Informations on plant and plant parts uses were collected interviewing key informants using semi-structured open-ended questionnaire. Altogether 45 different plant species of plants belonging to 31 families and 42 genera were documented and majority of them are trees. In terms of plant and plant parts use, seed or fruits and leaf are in top priorities. These plants are used to treat different ailments ranging from gastro-intestinal to headache and fever, respiratory tract related problems to dermatological problems, snake bite to ophthalmic and cuts and wounds. Easy access to modern medicines and less recognition of traditional healers are the main causes leading to decrease in interest of young generation in the use of traditional medicinal practices.
\end{abstract}

Keywords: Ethnobotany; Medicinal plants; Parroha VDC; Tharu.

\section{INTRODUCTION}

Traditional use of plant and plant resources for medicinal purpose has a long history in Nepal and its use is rapidly spreading due to having no side-effects, easily available at affordable prices and sometime the only source of health care available to the poor. The ethnic communities have significant customary knowledge on utilization of plant and plant parts and there is a long tradition of transferring this indigenous knowledge from generation to generation. The indigenous knowledge on medicinal plants is gaining recognition worldwide. In Nepal, Nepal Biodiversity Strategy has also highlighted its importance for proper conservation of Himalayan biodiversity (NBS, 2002).

The plant and plant resources for medicinal use are collected from various habitats. At present, most of these habitats with useful species are under threat due to habitat destruction, unsustainable harvesting and over-exploitation (Chaudhary, 1998) and many species are already threatened from collection pressure (Ghimire et al., 2005). If this trend of utilization of plant and plant resources remain same, we are in a danger of losing them forever (Manandhar, 2002). So, the priority should be given to the documentation of indigenous knowledge and conservation of the existing species and habitats before some of these are eliminated from the area (Joshi et al 2003).

The Tharus are a culturally and linguistically diverse ethnic group of Terai region and are also believed to be the first people to occupy the Terai region (Meyer \& Deuel, 1998). Among all ethnic groups, the Tharu is one of the largest tribe representing $6.8 \%$ of National population and $13.47 \%$ of Terai (CBS, 2001). They are found in close proximities in certain districts namely Kailali, Kanchanpur, Dang, Banke, Rupandehi, Kapilvastu, Chitwan, Nawalparasi, Parsa, Bara, Rautahat, Udayapur, Morang, Jhapa of Terai region and inner Terai region (Krauskopff, 1995). Over the time, the Tharus have developed a remarkable resistance to malaria which prevented other peoples' residence in this region. They have inhabited these plains for over 600 years which enabled the Tharus to develop a unique culture and tradition (Bista, 2004). After the malaria eradication in 1960s, the Terai region became the densely populated with the immigrants from higher elevations. But, the Tharus have been maintaining their ethnic and socio-cultural practices.

The traditional healing practice of the Tharus is limited to certain key member of the society, they communicate these knowledge orally from generation to generation. In this context, some sporadic works have been already done to collect ethnobotanical data and traditional knowledge systems of Tharu community (Manandhar 1985, Dangol \& Gurung 1991, Thapa 2001, Chapagain et al 2004, Ghimire \& Bastakoti 2009). However, the ethnobotanical information of Tharu community of Parroha VDC is still undocumented. In

Author for Correspondence: Kamal Prasad Acharya, P.O. Box 15142 KPC 676, Kathmandu, Nepal. E-mail: acharya.kamal@gmail.com. 
this background, present study was devised to document the traditional knowledge on medicinal plants with their indigenous uses and practices.

\section{MATERIALS AND METHODS}

\section{Study Area}

Parroha VDC is located in Rupandehi district which lies between $27^{\circ} 20^{\prime}$ to $27^{\circ} 45^{\prime} \mathrm{N}$ latitude and $83^{\circ} 10^{\prime}$ to $83^{\circ} 30^{\prime} \mathrm{E}$ longitude. It is a part of the Terai region of Nepal and covers a total area of $73196.1 \mathrm{ha}^{2}$ of which about $73 \%$ is agricultural land, urban areas, and roads, 23\% forest, and the remaining 4\% water resources (Anonymous, 2007). Present research was conducted in Parroha Community Forest of Parroha VDC with an area of 633 ha and lies in churia range of Nepal. The total population of VDC is about 20,000, of which about one fourth are Tharu (CBS 2002). The altitude of the district ranges from $220 \mathrm{~m}$ to $500 \mathrm{~m}$ a.s.l. The forest is mainly dominated by Sal (Shorea robutsa) with its associated species like Saj (Terminalia alata), Banjhi (Anogeissus latifolia) etc. The climate of the area is typically tropical dominated by the southeast monsoon. A hot climate generally prevails throughout the year except in the short winter. The temperature ranges from an average of $7^{\circ} \mathrm{C}$ in winter to an average of $45^{\circ} \mathrm{C}$ during summer.

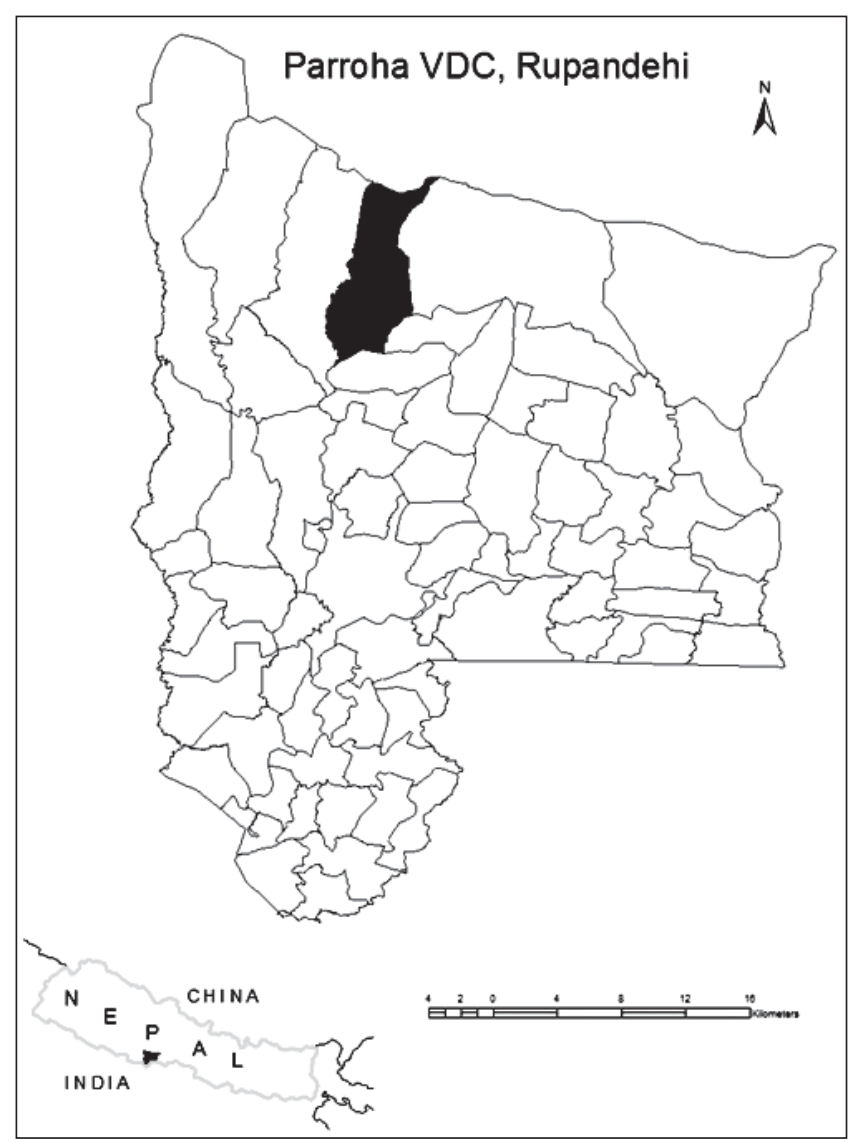

Figure 1. Map of the study area.

\section{Field study}

The study area was surveyed during different periods of the year 2007. Information on plant and plant parts uses was collected by interviewing key informants using a semistructured open-ended questionnaire. To collect plant species for herbarium preparation, key informants were employed. Some of the collected specimens were identified in the field, whereas others were identified with the help of standard literature (Polunin \& Stainton 1984, Stainton 1997) and with cross checking the specimens deposited at Tribhuvan University Central Herbarium (TUCH), Kirtipur. The nomenclature of the species follows Press et al. (2000). The collected specimens are deposited at TUCH.

\section{RESULTS AND DISCUSSION}

We collected informations on 45 medicinal plants species which fall under 42 genera and 31 families. List of medicinal plants with their scientific name, family, collection number, local name, life form, parts used and uses are presented in table 1 . The species are arranged alphabetically. Out of total species used for medicinal value, majority are trees (42\%) followed by herb (27\%), shrub (18\%) and climber (13\%) (Figure 2). The family Leguminosae is represented by the highest number of species (six species) followed by Combretaceae (three species), Rutaceae, Meliaceae, Asclepiadaceae, Poaceae, Moraceae, Apocynaceae, and Euphorbiaceae (two species each).

This study shows similar results with those reported in an earlier studies in Dang-Deokhuri district (Manandhar 1985), Chitwan district (Dangol \& Gurung 1991), and Nawalparasi district (Ghimire \& Bastakoti 2009). Out of 45 species documented for medicinal use in present study area, 23 species are reported by Ghimire \& Bastakoti (2009), 19 species by Chapagain et al. (2004), 18 species by Thapa (2001). However, nine species namely Asparagus racemosus, Bombax ceiba, Centella asiatica, Cynodon dactylon, Holarrhena pubescens, Mallotus philippensis, Phyllanthus emblica, Terminalia bellirica, and T. chebula are reported by all. But, 14 species reported in this study have not been reported in above mentioned references.

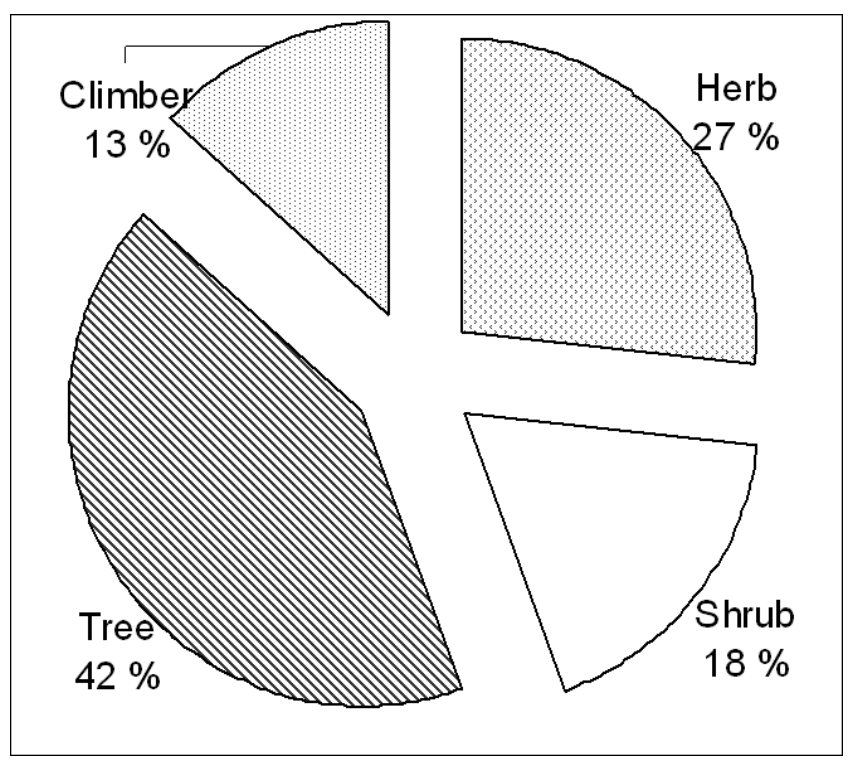

Figure 2: Different life forms of medicinal plants collected 


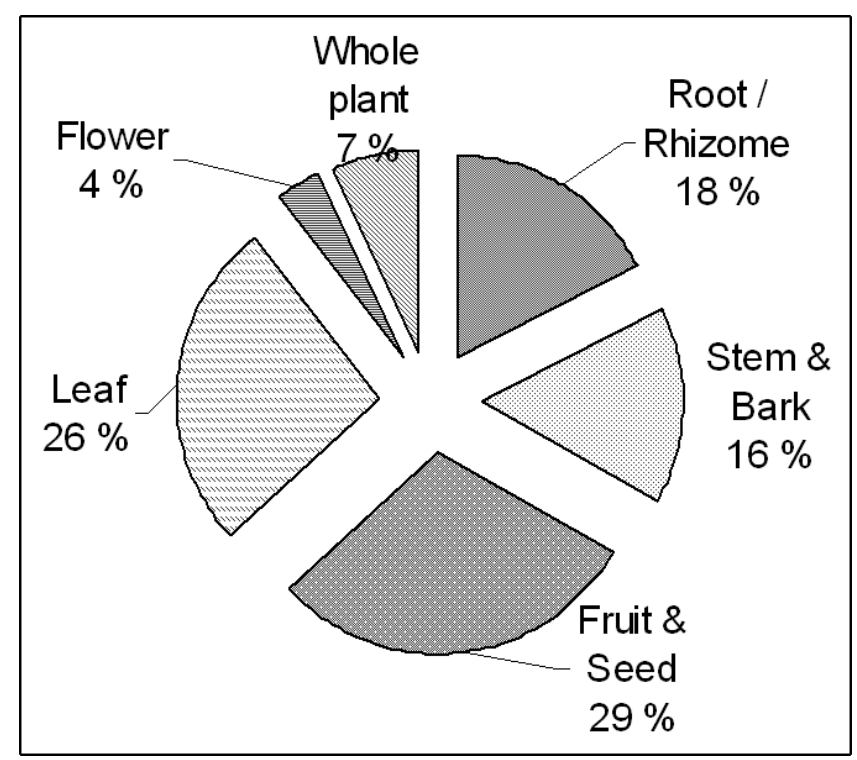

Figure 3: Graph showing plant and plant parts used

The plant parts widely used for medicinal purposes include the fruit or seed and leaf are used (each being 29\% and 26\% respectively) followed by root / rhizome (18\%), Stem/bark (16\%), whole plant 7\% and least the flower (4\%) (Figure 3).

Regarding different disease categories, we found that 26 medicinal plant species used to treat gastro-intestinal problems (dysentery, diarrhea, gastric, abdominal pain, ulcer etc.), 17 species are used to treat headache and fever, eight species are used to treat for respiratory tract related problems (cough/ cold and bronchial problem, asthma etc.), four species are used to cure dermatological problems (scabies, burns, swellings, and other skin related problems), two species for snake bite, and very less for ophthalmic and cuts and wounds (Table 1).
According to the key informants we interviewed during our study, many medicinal plants have been disappearing from the nearby forests. Because of which sometimes they have to walk far to collect medicinal plants that had earlier been easily available close to their villages. According to them, rapid deforestation and expansion of agricultural lands as well as destructive harvesting for commercial purposes are the main reasons for disappearance of medicinal plants.

The informations presented in this research are collected from the senior members of the community who are still practicing the traditional healing methods. This study showed that the elderly persons/traditional healers have greater knowledge upon the utilization of medicinal plants in comparison to younger generation. During our study period, we found some cases that the people are seeking help from the traditional healers when their illness was not cured by modern medicines. Low socio-economic status of the people has also compelled them to rely on traditional medicinal practices. When we interacted with younger generation of the society, they showed less interest in traditional practices mostly because of poor recognition of traditional healers and availability of modern health facilities. But, they are in positive that this type of knowledge which their forefathers followed should be documented before they are lost or disappeared. The trend of disinterest of young generation shows that the traditional knowledge on medicinal plants is deteriorating in present study area. To preserve these valuable natural resources, first these existing valuable informations are needed to be documented before they are lost or disappeared. Therefore, strong emphasis should be given for the documentation of indigenous uses, traditional knowledge and practices.

Table 1: List of medicinal plants with their scientific name, family and collection number with their local name, life form, parts used and uses:

\begin{tabular}{|c|c|c|c|c|c|}
\hline SN & Plant Species & Local Name & $\begin{array}{l}\text { Life } \\
\text { form }\end{array}$ & Parts Used & Uses \\
\hline 1 & $\begin{array}{l}\text { Abrus precatorius L. } \\
\text { LEGUMINOSAE } \\
\text { RA } 314\end{array}$ & Titihar (Th) & C & Seed & $\begin{array}{l}\text { Used to treat fever, stomach disease, eye disease, asthma } \\
\text { and uteral problem. }\end{array}$ \\
\hline 2 & $\begin{array}{l}\text { Acorus calamus L. } \\
\text { ARACEAE } \\
\text { RA } 319\end{array}$ & Katara (Th) & $\mathrm{H}$ & Rhizome & Used to treat cough, cold and bronchial Problem. \\
\hline 3 & $\begin{array}{l}\text { Aegle marmelos (L.) Correa } \\
\text { RUTACEAE } \\
\text { RA } 315\end{array}$ & $\operatorname{Bel}(\mathrm{N})$ & $\mathrm{T}$ & Ripe Fruit & Used to treat diarrhea and dysentery. \\
\hline 4 & $\begin{array}{l}\text { Asparagus racemosus var subacerosus } \\
\text { Baker } \\
\text { LILIACEAE } \\
\text { RA } 323\end{array}$ & Santawar (Th) & $\mathrm{s}$ & Root & $\begin{array}{l}\text { The powder or decoction of root is used } \\
\text { to relieve the burning sensation. } \\
\text { (Garmi ko lagi) }\end{array}$ \\
\hline 5 & $\begin{array}{l}\text { Azadirachta indica A. Juss. } \\
\text { MELIACEAE } \\
\text { RA } 317\end{array}$ & Neem $(\mathrm{N})$ & $\mathrm{T}$ & Leaf & $\begin{array}{l}\text { Decoction of leaves is used to reduce } \\
\text { sugar level, bark used as antirelmintic } \\
\text { and relieves cough. }\end{array}$ \\
\hline 6 & $\begin{array}{l}\text { Bassia butyracea Roxb. } \\
\text { SAPOTACEAE } \\
\text { RA } 333 \\
\end{array}$ & Chiuri (N) & $\mathrm{T}$ & Fruit and seed & $\begin{array}{l}\text { Oil from seed is used for massage to } \\
\text { relieve muscles pain. Also used as } \\
\text { astringent. }\end{array}$ \\
\hline 7 & $\begin{array}{l}\text { Bauhinia variegata L. } \\
\text { LEGUMINOSAE } \\
\text { RA } 347\end{array}$ & Koilara (Th) & $\mathrm{T}$ & Bark and stem & $\begin{array}{l}\text { Used as antidote in snake bite. Juice of } \\
\text { bark is used to treat dysentery. }\end{array}$ \\
\hline 8 & $\begin{array}{l}\text { Begonia picta Sm. } \\
\text { BEGONIACEAE } \\
\text { RA } 316\end{array}$ & Makarkanchi (N) & $\mathrm{H}$ & Leaf/Whole plant & $\begin{array}{l}\text { Juice of plant is used as slight venom. } \\
\text { Also used to relieve pains. }\end{array}$ \\
\hline 9 & $\begin{array}{l}\text { Bombax ceiba L. } \\
\text { LEGUMINOSAE } \\
\text { RA } 328\end{array}$ & Semal (Th) & $\mathrm{T}$ & Fruit, bark & $\begin{array}{l}\text { Juice of bark is used to treat urinary } \\
\text { disord, excessive vaginal bleeding and } \\
\text { intestine bleeding. }\end{array}$ \\
\hline 10 & $\begin{array}{l}\text { Calotropis gigantea (L.) Dryand. } \\
\text { ASCLEPIADACEAE } \\
\text { RA } 307\end{array}$ & Madar (Th) & $\mathrm{s}$ & Fruit, leaves & $\begin{array}{l}\text { Used to treat body pains, boils and } \\
\text { pimples. }\end{array}$ \\
\hline
\end{tabular}




\begin{tabular}{|c|c|c|c|c|c|}
\hline SN & Plant Species & Local Name & $\begin{array}{l}\text { Life } \\
\text { form }\end{array}$ & Parts Used & Uses \\
\hline 11 & $\begin{array}{l}\text { Careya arborea Roxb. } \\
\text { LECYTHIDACEAE } \\
\text { RA } 324\end{array}$ & Kumbhi (Th) & $\mathrm{T}$ & Bark, fruit & $\begin{array}{l}\text { Acts as medicine in wound, diarrhea, } \\
\text { fever and snake bite. }\end{array}$ \\
\hline 12 & $\begin{array}{l}\text { Centella asiatica (L.) Urb. } \\
\text { UMBELLIFERAE } \\
\text { RA } 321\end{array}$ & Bhatbhate (Th) & $\mathrm{H}$ & Whole plant/leaf & $\begin{array}{l}\text { Leaves are used as tonic, enhances } \\
\text { memory, used to cure skin disease, to } \\
\text { treat nerve troubles. }\end{array}$ \\
\hline 13 & $\begin{array}{l}\text { Cuscuta reflexa var brachystigma Engelm } \\
\text { CONVOLVULACEAE } \\
\text { RA } 327\end{array}$ & Baora (Th) & $\mathrm{C}$ & All parts & $\begin{array}{l}\text { Paste of plant is used to treat } \\
\text { stomachache, headache and body } \\
\text { pain. Also used to treat jaundice. }\end{array}$ \\
\hline 14 & $\begin{array}{l}\text { Cynodon dactylon (L.) Pers. } \\
\text { POACEAE } \\
\text { RA } 318 \\
\end{array}$ & Dub (Th) & $\mathrm{H}$ & Leaf & $\begin{array}{l}\text { Plant paste is used in cuts and wounds, } \\
\text { to cure haematuria and scabies. }\end{array}$ \\
\hline 15 & $\begin{array}{l}\text { Cyperus rotundus L. } \\
\text { CYPERACEAE } \\
\text { RA } 322\end{array}$ & Motha/Bhada (Th) & $\mathrm{H}$ & Leaf/Root & $\begin{array}{l}\text { Used to treat indigestion, diarrhea, } \\
\text { vomiting, cough, bronchitis, fever }\end{array}$ \\
\hline 16 & $\begin{array}{l}\text { Dalbergia latifolia Roxb. } \\
\text { LEGUMINOSAE } \\
\text { RA } 331\end{array}$ & Satisal (N) & $\mathrm{T}$ & Root/Bark & $\begin{array}{l}\text { The decoction of the roots or wood is } \\
\text { used to treat bodyache. }\end{array}$ \\
\hline 17 & $\begin{array}{l}\text { Dioscorea deltoidea Wall. ex Griseb. } \\
\text { DIOSCOREACEAE } \\
\text { RA } 308 \\
\end{array}$ & Gittha (N) & $\mathrm{C}$ & Fruit/Comb & $\begin{array}{l}\text { Boiled fruit are used to cure stomach pain } \\
\text { and boiled comb are used as vegetables. }\end{array}$ \\
\hline 18 & $\begin{array}{l}\text { Dryopteris sp. } \\
\text { ASPIDACEAE } \\
\text { RA } 325 \\
\end{array}$ & Damsinki (N) & $\mathrm{H}$ & Leaf & $\begin{array}{l}\text { Extract of leaves is used to cure gastric, } \\
\text { ulcer and worms. }\end{array}$ \\
\hline 19 & $\begin{array}{l}\text { Ficus benghalensis L. } \\
\text { MORACEAE } \\
\text { RA } 330 \\
\end{array}$ & Bargat (Th) & $\mathrm{T}$ & Bark & $\begin{array}{l}\text { An infusion of bark is used in } \\
\text { diarrhea, dysentery and diabetes. }\end{array}$ \\
\hline 20 & $\begin{array}{l}\text { Ficus semicordata Buch.-Ham. ex Sm. } \\
\text { MORACEAE } \\
\text { RA } 351\end{array}$ & Khurhur (Th) & $\mathrm{T}$ & Root/Young leaf & $\begin{array}{l}\text { Juice of root is applied to treat } \\
\text { headache and fever. }\end{array}$ \\
\hline 21 & $\begin{array}{l}\text { Gaultheria fragrantissima Wall. } \\
\text { ERICACEAE } \\
\text { RA } 332\end{array}$ & Pakbherni (Th) & $\mathrm{S}$ & Leaf & $\begin{array}{l}\text { Its leaf oil is used in massage to get } \\
\text { relief from par of head, legs and hands. }\end{array}$ \\
\hline 22 & $\begin{array}{l}\text { Holarrhena pubescens (Buch.-Ham.) Wall. } \\
\text { ex G. Don } \\
\text { APOCYNACEAE } \\
\text { RA } 320\end{array}$ & Kacheri (Th) & $\mathrm{T}$ & Bark/Fruit & $\begin{array}{l}\text { Juice of bark is used to treat } \\
\text { dysentery, seed-astringent, febrifuge, } \\
\text { also used to treat diarrhea and worms }\end{array}$ \\
\hline 23 & $\begin{array}{l}\text { Inula cappa (Buch.-Ham. ex D. Don) DC } \\
\text { COMPOSITAE } \\
\text { RA } 332 \\
\end{array}$ & Pataya (Th) & $\mathrm{S}$ & Root & $\begin{array}{l}\text { Used to treat fever and headache, } \\
\text { useful to reduce disorders arose } \\
\text { due to in take of meat. }\end{array}$ \\
\hline 24 & $\begin{array}{l}\text { Justicia adhatoda L. } \\
\text { ACANTHACEAE } \\
\text { RA } 303\end{array}$ & Asuro/rus (N) & $\mathrm{S}$ & Leaf & $\begin{array}{l}\text { Leaves are used to treat cough, } \\
\text { Fever and bronchitis. }\end{array}$ \\
\hline 25 & $\begin{array}{l}\text { Mallotus philippensis (Lam.) Müller.-Arg. } \\
\text { EUPHORBIACEAE } \\
\text { RA } 334\end{array}$ & Rohini (Th) & $\mathrm{T}$ & Bark & $\begin{array}{l}\text { Juice of bark is used to treat } \\
\text { diarrhea, dysentery and bronchitis. }\end{array}$ \\
\hline 26 & $\begin{array}{l}\text { Marsdenia tinctoria } \text { R.Br. } \\
\text { ASCLEPIADACEAE } \\
\text { RA } 329 \\
\end{array}$ & Dudhelaharo (N) & $\mathrm{C}$ & Flower & $\begin{array}{l}\text { It is energetic and used in gout, } \\
\text { disorder of thymus and also } \\
\text { and supposed to purify blood. }\end{array}$ \\
\hline 27 & $\begin{array}{l}\text { Melia azedarach } \mathrm{L} . \\
\text { MELIACEAE } \\
\text { RA } 309 \\
\end{array}$ & Bakaino (N) & $\mathrm{T}$ & Fruit & $\begin{array}{l}\text { Fruit is anthelmintic, also used for } \\
\text { treat vomitting, blood impurities } \\
\text { and urinary discharge. }\end{array}$ \\
\hline 28 & $\begin{array}{l}\text { Mentha spicata L. } \\
\text { LABIATAE } \\
\text { RA } 310 \\
\end{array}$ & Bawari (Th) & $\mathrm{H}$ & Leaves & $\begin{array}{l}\text { Leaves decoction is used to treat } \\
\text { cure throat infection and } \\
\text { indigestion }\end{array}$ \\
\hline 29 & $\begin{array}{l}\text { Milletia extensa (Benth.) Baker } \\
\text { LEGUMINOSAE } \\
\text { RA } 313\end{array}$ & Pakverni (Th) & $\mathrm{C}$ & Leaves/Roots & $\begin{array}{l}\text { Leaves are used to treat goat's and } \\
\text { other animal's lice, and worms. }\end{array}$ \\
\hline 30 & $\begin{array}{l}\text { Murraya koenigii (L.) Spreng. } \\
\text { RUTACEAE } \\
\text { RA } 350 \\
\end{array}$ & Ban neem (Th) & $\mathrm{T}$ & Fruit/Leaf & $\begin{array}{l}\text { Used to control fleas, repellent for other insects, leaves } \\
\text { used to treat } \\
\text { diarrhea and dysentery. }\end{array}$ \\
\hline 31 & $\begin{array}{l}\text { Orchid sp } \\
\text { ORCHIDACEAE } \\
\text { RA } 326 \\
\end{array}$ & Sunakhari (N) & $\mathrm{H}$ & Pseudobulb & $\begin{array}{l}\text { The paste of the pseudobulb is used to } \\
\text { clear scars and marks in face. }\end{array}$ \\
\hline 32 & $\begin{array}{l}\text { Oxalis corniculata Tayl. } \\
\text { OXALIDACEAE } \\
\text { RA } 311\end{array}$ & Chamchama (Th) & $\mathrm{H}$ & Whole plant & $\begin{array}{l}\text { Juice of plant is used to treat diarrhea, } \\
\text { dysentery, fever. Refrigerant. }\end{array}$ \\
\hline 33 & $\begin{array}{l}\text { Parmelia nepalensis Tayl. } \\
\text { PARMELIACEAE } \\
\text { RA } 287\end{array}$ & Jhyau (N) & $\mathrm{H}$ & All parts & $\begin{array}{l}\text { Used in disease of gum, throat as well as } \\
\text { in scabies, piles and leprosy. }\end{array}$ \\
\hline 34 & $\begin{array}{l}\text { Phyllanthus emblica L. } \\
\text { EUPHORBIACEAE } \\
\text { RA } 353 \\
\end{array}$ & Amala $(\mathrm{N})$ & $\mathrm{T}$ & Seed/Fresh fruit & $\begin{array}{l}\text { One of the constituents of triphala which } \\
\text { is used for gastritis, for cooling, diuretic } \\
\text { and laxative source of vitamin C }\end{array}$ \\
\hline 35 & $\begin{array}{l}\text { Piper longum L. } \\
\text { PIPERACEAE } \\
\text { RA } 341\end{array}$ & Kharipipar (Th) & $\mathrm{C}$ & Fruit & $\begin{array}{l}\text { Fruit used for cough (khoki, dam) and for } \\
\text { digestion }\end{array}$ \\
\hline 36 & $\begin{array}{l}\text { Plantago major L. } \\
\text { PLANTAGINACEAE } \\
\text { RA } 306\end{array}$ & Bhatbhadwa (Th) & $\mathrm{H}$ & Seed \& seed husk & $\begin{array}{l}\text { Used to treat fever, diarrhea and dysentry, } \\
\text { laxative demulcent, expectorant, } \\
\text { diuretic. }\end{array}$ \\
\hline 37 & $\begin{array}{l}\text { Pterocarpus marsupium Roxb. } \\
\text { LEGUMINOSAE } \\
\text { RA } 352\end{array}$ & Bijaya sal (N) & $\mathrm{T}$ & Stem & $\begin{array}{l}\text { The paste of the stem is used in case of } \\
\text { tingling (Jham Jham garne) or neurological } \\
\text { problem. }\end{array}$ \\
\hline
\end{tabular}




\begin{tabular}{|c|c|c|c|c|c|}
\hline SN & Plant Species & Local Name & $\begin{array}{l}\text { Life } \\
\text { form }\end{array}$ & Parts Used & Uses \\
\hline 38 & $\begin{array}{l}\text { Rauvolfia serpentina (L.) Benth. ex Kurz } \\
\text { APOCYNACEAE } \\
\text { RA } 305\end{array}$ & $\begin{array}{l}\text { Sarpagandha/ } \\
\text { Dhaldhaliya (Th) }\end{array}$ & S & Fruit & $\begin{array}{l}\text { Reduce blood pressure, hypotonic also } \\
\text { used to treat dysentery. }\end{array}$ \\
\hline 39 & $\begin{array}{l}\text { Scurrula elata (Edgew.) Danser } \\
\text { LORANTHACEAE } \\
\text { RA } 306\end{array}$ & Aainjeru (N) & S & Leaf & Used to reduce the joint pain. \\
\hline 40 & $\begin{array}{l}\text { Semecarpus anacardium L.f. } \\
\text { ANACARDIACEAE } \\
\text { RA } 335\end{array}$ & Bhela (Th) & $\mathrm{T}$ & Fruit & $\begin{array}{l}\text { Fruit used to cure dysentery, asthma } \\
\text { and acute rheumatism }\end{array}$ \\
\hline 41 & $\begin{array}{l}\text { Terminalia alata Heyne ex Roth } \\
\text { COMBRETACEAE } \\
\text { RA } 349\end{array}$ & Asna (Th) & $\mathrm{T}$ & Bark & $\begin{array}{l}\text { Fresh bark juice is used to cure } \\
\text { diarrhea and dysentery. }\end{array}$ \\
\hline 42 & $\begin{array}{l}\text { Terminalia bellirica (Gaertn.) Roxb. } \\
\text { COMBRETACEAE } \\
\text { RA } 348\end{array}$ & Barro (N) & $\mathrm{T}$ & Fruit & $\begin{array}{l}\text { Fruit used to remedyin cough and eye } \\
\text { disease one of the constituents of triphala. }\end{array}$ \\
\hline 43 & $\begin{array}{l}\text { Terminalia chebula Retz. } \\
\text { COMBRETACEAE } \\
\text { RA } 347\end{array}$ & Harro $(\mathrm{N})$ & $\mathrm{T}$ & Fruit & $\begin{array}{l}\text { The fruit is one of the constituents of } \\
\text { triphala that is used for gastritis. }\end{array}$ \\
\hline 44 & $\begin{array}{l}\text { Thysanolaena maxima (Roxb.) Kuntze } \\
\text { POACEAE } \\
\text { RA } 336 \\
\end{array}$ & Bankucho (Th) & $\mathrm{H}$ & Root & Root juice is antihelmintic. \\
\hline 45 & $\begin{array}{l}\text { Woodfordia fruticosa (L.) Kurz } \\
\text { LYTHRACEAE } \\
\text { RA } 304\end{array}$ & Dhawatha (Th) & S & Flower/Leaf/Root & $\begin{array}{l}\text { Used to reduce labour pain, to control } \\
\text { bleeding and to maintain healthy } \\
\text { condition of newborn child. }\end{array}$ \\
\hline
\end{tabular}

Local name-(Th): Tharu name, (N): Nepali name; Life form - H: Herb; S: Shrub; T: Tree; C: Climber;

\section{CONCLUSION}

Present study shows that the study area is rich in medicinal plants. Tharu community has developed their own unique system of using plants for medicinal uses. The elderly people of a community have greater knowledge on medicinal plants. But, the youngsters of the study area showed less interest in traditional practices mainly due to less recognition of traditional healers and easy availability of modern medicines. Because of which the practice of using plants and plant parts for medicinal use is decreasing. So, the emphasis should be given for the documentation of this knowledge before they are lost or disappeared.

\section{ACKNOWLEDGEMENTS}

We are thankful to the local resource person for sharing valuable informations on plants and plant resources. Thanks to anonymous reviewer for his/her valuable comments in the initial version of this manuscript.

\section{REFERENCES}

Anonymous. 2007. Rupandehi Jilla ek Parichaya (In Nepali). District Development Committee, Rupandehi District, Nepal.

Bista, D.B. 2004. People of Nepal. Ratna Pustak Bhandar, Kathmandu, Nepal.

CBS. 2001. Population Monograph of Nepal. Central Bureau of Statistics, Thapathali, Kathmandu, Nepal.

CBS. 2002. Population of Nepal: Caste/Ethnicity, Mother Tongue and Religion (Western Development Region). Central Bureau of Statistics, Thapathali, Kathmandu, Nepal.

Chapagain, D.J., Joshi, S.D. and Jnawali, S.R. 2004. Use of medicinal plants by tharu community in the southwestern buffer zone of royal bardia national park. Scientific World. 2(2): 50-62.

Chaudhary, R.P. 1998. Biodiversity in Nepal (Status and Conservation). S. Devi, Saharanpur (U.P.), India and Tecpress Books, Bangkok, Thailand.
Dangol, D.R. and Gurung, S.B. 1991. Ethnobotany of the Tharu tribe of Chitwan District, Nepal. International Journal Pharmacognosy. 29(3): 203-209.

Ghimire, S.K., MsKeyD. and Yildiz, A.T. 2005 Conservation of Himalayan medicinal plants: Harvesting patterns and ecology of two threatened species, Nardostachys grandiflora DC. and Neopicrorhiza scrophulariiflora (Pennell) Hong. Biological Conservation. 124: 463-475.

Joshi, A.R., Shrestha, S.L. and Joshi, K. 2003. Environmental Management and Sustainable Development at the Crossroad. AnKus, Kathmandu, Nepal.

Krauskopff, G. 1995. The Anthropology of the Tharus: An Annoted Bibliography. Kailash Himalaya. 17 (3\&4): 185-213.

Manandhar, N.P. 1985. Ethnobotanical notes on certain medicinal plants used by Tharus of Dang Deokhuri District, Nepal. International Journal Crude Drug Research. 23(4): 153-159.

Manandhar, N.P. 2002. Plants and People of Nepal. Timber Press Portland, Oregon, USA.

Meyer, K. and Deuel, P. 1998. Mahabhrata: The Tharu Barka Naach. Himal Books, Lalitpur, Nepal.

NBS. 2002. Nepal Biodiversity Strategy. His Majesty’s Government of Nepal, Ministry of Forest and Soil Conservation, Kathmandu, Nepal.

Polunin, O. and Stainton, A. 1984. Flowers of the Himalaya. Oxford University Press, Oxford. Pp. 580.

Press, J.R., Shrestha, K.K. and Sutton, D.A. 2000. Annotated checklist of the flowering plants of Nepal. The Natural History Museum, London.

Stainton, A. 1997. Flowers of the Himalaya: A Supplement. Oxford University Press, Oxford.

Thapa, S. 2001. Documentation of Traditional Uses of Plants by Tharu Community around Royal Shuklaphanta Wildlife Reserve, Far-Western Nepal. MSc Dissertation, Central Department of Botany, Tribhuvan University, Kathmandu, Nepal. 